\title{
Analisa karakteristik aliran pada fenomena sirkulasi alam fasa-tunggal di Untai FASSIP-01 Mod.2
}

\author{
Nathaniel Ezer Putra Darmawan ${ }^{1}{ }^{\star}$, G.B. Heru $\mathrm{K}^{2)}$, \\ Dedy Haryanto ${ }^{2)}$, Giarno2), I Nyoman Suprapta Winaya ${ }^{1)}$, I Ketut Gede Sugita1), \\ Putu Brahmanda Sudarsana ${ }^{1)}$, Mulya Juarsa ${ }^{2)^{*}}$ \\ ${ }^{1)}$ Program Studi Teknik Mesin, Fakultas Teknik, Universitas Udayana, JI. Raya Kampus UNUD, Bukit \\ Jimbaran, Kuta Selatan,Kab. Badung, Bali, 80361. \\ ${ }^{2)}$ Pusat Teknologi dan Keselamatan Reaktor Nuklir, Badan Tenaga Nuklir Nasional, Gedung 80, \\ Kawasan Puspiptek, Serpong, Tangerang Selatan,15130.
}

Naskah diterima 20/06/2021; direvisi 23/09/2021; disetujui 30/09/2021 doi: https://doi.org/10.24843/JEM.2021.v14.i02.p04

\begin{abstract}
Abstrak
Untai FASSIP-01 merupakan salah satu fasilitas yang dimiliki oleh PTKRN-BATAN yang digunakan untuk meneliti fenomena sirkulasi alam yang terjadi dalam skala besar. Fenomena sirkulasi alam ini nantinya akan diterapkan sebagai sistem pendingin pasif pada PLTN yang akan didirikan di Indonesia. Beberapa eksperimen yang dilakukan pada untai FASSIP-01 sebelumnya menunjukkan laju aliran yang tidak optimal dikarenakan terdapat beberapa error yang menyebabkan kerugian pada aliran. Modifikasi kedua yang dilakukan pada untai FASSIP-01 bertujuan untuk meminimalkan error yang terjadi. Tujuan penelitian ini adalah untuk mengetahui karakteristik aliran dan pergerakkan data yang dihasilkan aliran pada untai FASSIP-01 mod.2 sebelum melakukan eksperimen. Analisa dilakukan dengan melakukan simulasi menggunakan aplikasi. Simulasi dilakukan dengan menggunakan gambar 2 dimensi serta memvariasikan Temperatur pemanas pada $353,15 \mathrm{~K}$ dan $363,15 \mathrm{~K}$ serta pendingin pada Temperatur $278,15 \mathrm{~K}, 283,15$ K, 288,15 K dan 293,15 K. Berdasarkan hasil simulasi diketahui bahwa cepat laju aliran akan bertambah jika Temperatur pada tangki pemanas di naikkan, tetapi akan menurun jika Temperatur pada tangki pendingin dinaikkan. Hasil perhitungan Bilangan Reynold dan Bilangan Nusselt berdasarkan cepat laju aliran adalah 2973,668 paling rendah dan 5775,356 paling tinggi dan untuk Bilangan Nusselt didapatkan 17,36 paling rendah dan paling tinggi 28,091.
\end{abstract}

Kata Kunci: FASSIP-01, modifikasi 2, sirkulasi alam, laju aliran, aliran massa.

\begin{abstract}
FASSIP-01 rectangular loop is a facility which owned by PTKRN-BATAN that used for observe the phenomenon of natural circulation in large-scale. This natural circulation phenomenon will be applied as a passive cooling system in nuclear power plant that will be built up in Indonesia. Some FASSIP-01 experiments have done before, but those experiments show that the fluid flow in FASSIP-01 is not in optimal conditions because there are some errors happened and causes some losses. The second modification of FASSIP-01 rectangular loop has purpose to minimize losses happened in previous modification of FASSIP-01. The purpose of this research is to know the characteristics of flow and the trend of the data from the flow in FASSIP-01 mod.2 rectangular loop before do experiments. Simulations is done by using 2-dimensional images and varying the heating temperature at $353,15 \mathrm{~K}$ and $363,15 \mathrm{~K}$ and the cooler at temperatures of $278.15 \mathrm{~K}, 283.15 \mathrm{~K}, 288.15 \mathrm{~K}$ and $293.15 \mathrm{~K}$. Based on the simulation results it is known that the velocity flow rate will increase if the temperature in the heating tank is increased, but will decrease if the temperature in the cooling tank is increased. The results of the calculation of the Reynold Number and Nusselt Number based on the velocity flow rate are 2973,668 the lowest and 5775,356 the highest and for the Nusselt number obtained 17,36 and the highest is 28,091 .
\end{abstract}

Keywords: FASSIP-01, second modification, natural circulation, flow rate, mass flow.

\section{Pendahuluan}

Indonesia saat ini sedang merencanakan pembangunan PLTN pertama sebagai langkah dari penerapan energi baru dan terbarukan untuk mengurangi dampak polusi yang diakibatkan PLTU dan untuk memenuhi kebutuhan energi listrik yang terus meningkat setiap tahun. Banyak studi yang telah dilakukan sebagai bentuk persiapan dari penerapan PLTN di Indonesia [1]. Salah satu studi yang dilakukan adalah tentang pengaplikasian sistem keamanan pasif pada reaktor nuklir. Studi ini dilakukan sebagai bentuk pencegahan agar kejadian yang dialami reaktor di Fukushima tidak terulang [2]. Badan Tenaga Nuklir Nasional (BATAN) sebagai lembaga penelitian yang bertanggung jawab untuk ini telah membangun banyak fasilitas dan alat untuk kelancaran studi ini, dan salah satu alatnya adalah untai FASSIP-01.

Untai Fasilitas Simulasi Sistem Pasif 01 (FASSIP-01) merupakan alat yang digunakan untuk meneliti laju aliran pada fenomena sirkulasi alam [3]. Fenomena sirkulasi alam merupakan sebuah fenomena dimana fluida akan bergerak mengikuti bentuk loop tanpa adanya bantuan 
energi dari luar. Fenomena sirkulasi alam menggunakan konsep gaya buoyancy dengan memanfaatkan beda densitas air. Perbedaan densitas air disebabkan oleh pemanasan dan pendinginan yang terjadi pada untai FASSIP-01. Fenomena sirkulasi alam ini nantinya akan diaplikasikan pada reaktor nuklir yang akan dibangun di Indonesia [3]. Beberapa eksperimen telah dilakukan menggunakan untai FASSIP-01 dan hasilnya menunjukkan laju aliran yang tidak optimal yang diakibatkan beberapa error seperti bentuk geometri FASSIP-01 yang menyebabkan aliran kehilangan tekanan (pressure drop) hingga kinerja dari pemanas dan pendingin yang tidak optimal (seperti banyaknya terjadi heat loss) sehingga pemanasan dan pendinginan fluida tidak dapat maksimal. Beberapa modifikasi telah dilakukan untuk mengurangi error yang terjadi namun masih belum menunjukkan laju aliran yang optimal. Karena laju aliran yang optimal belum didapatkan, maka dari itu untai FASSIP-01 akan dimodifikasi untuk kedua kalinya.

Modifikasi kedua untai FASSIP-01 akan mengubah desain pada untai FASSIP-01. Pada untai FASSIP-01 dan FASSIP-01 mod.1 menggunakan 32 section dan 4 elbow, sedangkan untai FASSIP-01 mod.2 akan menggunakan 8 section dan 4 elbow. Modifikasi pada desain ini dilakukan setelah diketahui bahwa banyaknya section yang digunakan pada menyebabkan kelelahan pada aliran sehingga aliran mengalami kehilangan tekanan (pressure drop). Pengurangan section yang dilakukan diharapkan mampu mengurangi pressure drop yang tejadi pada eksperimen untai FASSIP-01 selanjutnya. Namun, sebelum eksperimen dilakukan, perlu dilakukan simulasi terhadap eksperimen yang akan dilakukan untuk mengetahui trend data yang akan terbentuk dari hasil eksperimen. Hasil simulasi ini nantinya bisa dijadikan sebagai acuan untuk mengetahui optimal atau tidaknya laju aliran pada eksperimen untai FASSIP-01 mod.2.

\section{Metode Penelitian}

\subsection{Geometri FASSIP-01 Mod.2.}

Komponen utama pada untai FASSIP-01 mod.2 terdiri atas pipa yang terdiri dari 6 section, sebuah tangki pemanas, sebuah tangki pendingin dan 4 buah elbow. Gambar 1 adalah rancangan desain untai FASSIP-01 mod.2.

\subsubsection{Section Dan Elbow}

Section pada untai FASSIP-01 mod.2 berfungsi sebagai perantara untuk mengalirkan Berdasarkan gambar 2, dapat dilihat bahwa setiap section dan elbow dapat terhubung dengan menggunakan flange. Flange yang digunakan nantinya akan diabaikan pada gambar simulasi karena dianggap tidak berpengaruh pada laju aliran eksperimen.
Fluida dari satu bagian ke bagian yang lainnya [4]. Pipa yang digunakan pada seluruh section berbahan dasar stainless steel SS304 [4]. Section pada FASSIP-01 mod.2 memiliki ukuran yang berbeda-beda. Tabel 1 berikut akan menjabarkan ukuran setiap section pada untai FASSIP-01 $\bmod 2$.

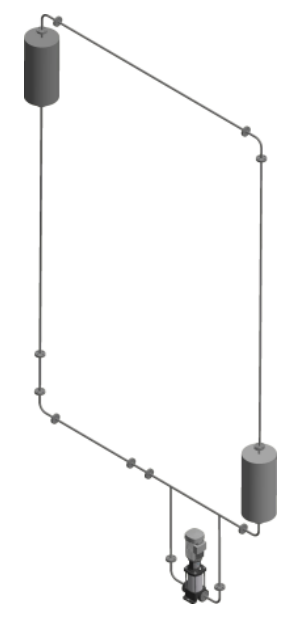

Gambar 1. Desain untai FASSIP-01 mod.2.

Ukuran masing-masing komponen dibahas pada sub-bab berikut.

Tabel 1. Ukuran setiap section pada untai FASSIP01 mod.2.

\begin{tabular}{lc}
\hline \multicolumn{1}{c}{ Geometri } & Ukuran $(\mathbf{m})$ \\
\hline Diameter dalam pipa & 0,0254 \\
Tebal pipa & 0,004 \\
Panjang section atas & 3 \\
$\begin{array}{l}\text { Panjang section bawah } \\
\text { bagian kiri }\end{array}$ & 1,21 \\
$\begin{array}{l}\text { Panjang section bawah } \\
\text { bagian tengah }\end{array}$ & 0,29 \\
$\begin{array}{l}\text { Panjang section bawah } \\
\text { bagian kanan }\end{array}$ & 1,5 \\
$\begin{array}{l}\text { Panjang section kanan } \\
\text { Panjang section kiri }\end{array}$ & 4,68 \\
\hline
\end{tabular}

Setiap section akan terhubung sehingga membentuk loop berbentuk persegi panjang. Section dengan arah horizontal dan arah vertikal akan dihubungkan menggunakan elbow.

Elbow pada untai FASSIP-01 mod.2 juga memiliki bahan dasar yang sama seperti section. 4 buah elbow yang terdapat pada untai FASSIP-01 mod. 2 memiliki sudut bend sebesar $90^{\circ}$. Panjang masing-masing dari pipa dengan arah vertikal dan arah horizontal pada elbow adalah 0,25 meter. 
Berikut merupakan gambar dari section dan elbow yang digunakan pada untai FASSIP-01 mod.2.

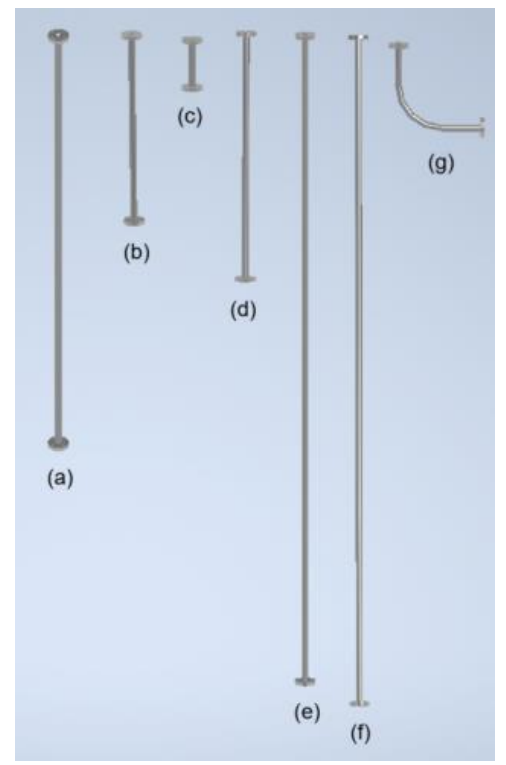

Gambar 2. Pipa untuk section (a) atas; (b) bawah bagian kiri; (c) bawah bagian tengah; (d) bawah bagian kanan; (e) kanan; (f) kiri; (g) Gambar elbow pada untai FASSIP-01 mod.2.

\subsubsection{Tangki Pemanas}

Tangki pemanas merupakan sebuah komponen yang difungsikan sebagai proyeksi reaktor nuklir yang menghasilkan panas [5]. Tangki pemanas akan diisi oleh air dan air tersebut akan dipanaskan dengan bantuan pemanas. Air yang telah panas tersebut digunakan untuk memanaskan fluida yang mengalir pada untai FASSIP-01 mod.2. Fluida yang dipanaskan oleh tangki pemanas akan memiliki densitas yang lebih rendah dan akan terdorong ke atas. Tangki pemanas yang digunakan pada untai FASSIP-01 mod.2 ditunjukkan pada gambar 3 .

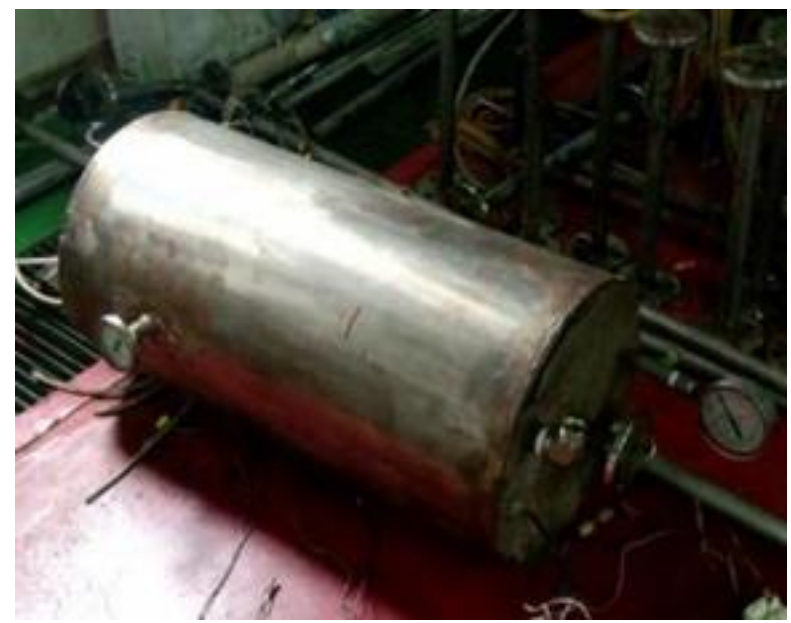

Gambar 3. Tangki pemanas pada untai FASSIP-01 mod.2.
Geometri dari tangki pemanas yang digunakan pada untai FASSIP-01 mod.2 ditampilkan pada tabel 2 .

Tabel 2. Geometri tangki pemanas pada untai FASSIP-01 mod.2.

\begin{tabular}{lc}
\hline Komponen dan Ukuran & Besar \\
\hline Daya Maksimal Pemanas & $5000 \mathrm{~W} / 240 \mathrm{~V}$ \\
Daya 4 Unit Pemanas & $20000 \mathrm{~W}$ \\
Diameter & $0,4 \mathrm{~m}$ \\
Tinggi & $0,82 \mathrm{~m}$ \\
Tebal & $0,004 \mathrm{~m}$ \\
Temperatur & 353,15 dan 363,15 \\
Volume Tangki Air & (temperatur simulasi) \\
Pemanas & 103,7 liter \\
\hline
\end{tabular}

Tangki pemanas pada FASSIP-01 mod.2 dilengkapi dengan 4 unit pemanas dengan masingmasing pemanas berdaya $5000 \mathrm{~W}$. Tangki pemanas dapat diisi oleh air hingga 103,7 liter. Tinggi tangki adalah 0,82 $\mathrm{m}$ dan belum termasuk dengan pipa penghubung tangki dengan flange. Diameter dan tebal tangki adalah 0,4 m dan 0,004 $\mathrm{m}$. Simulasi dilakukan dengan memvariasikan Temperatur tangki pemanas pada Temperatur $353,15 \mathrm{~K}$ dan $363,15 \mathrm{~K}$.

\subsubsection{Tangki Pendingin}

Tangki pendingin pada FASSIP-01 mod.2 berfungsi layaknya pendingin pada reaktor nuklir yang melepaskan kalor ke lingkungan[4]. Prinsip kerja dari tangki pendingin sama dengan prinsip kerja tangki pemanas, hanya saja jika tangki pemanas memakai pemanas untuk memanaskan air dalam tangki, maka tangki pendingin menggunakan bantuan dari refrigerator untuk mendinginkan air di dalam tangki. Gambar dari tangki pendinigin yang digunakan pada untai FASSIP-01 mod.2 ditunjukkan oleh gambar 4.

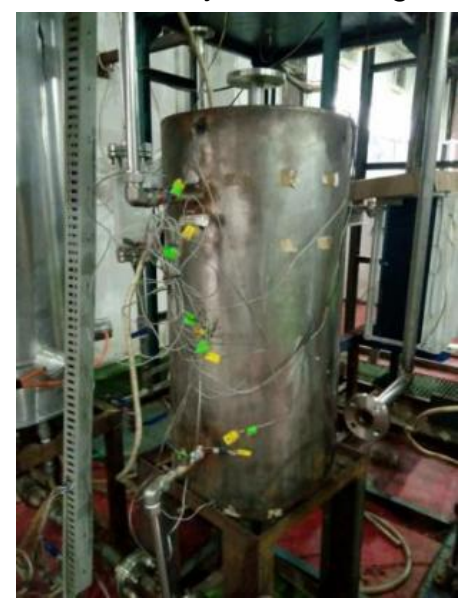

Gambar 4. Tangki pendingin pada untai FASSIP-01 $\bmod 2$. 
Selain gambar, berikut merupakan rincian geometri pendingin yang digunakan pada untai FASSIP-01 modifikasi 2.

Tabel 3. Komponen dan ukuran tangki pendingin pada untai FASSIP-01 mod.2.

\begin{tabular}{ll}
$\begin{array}{c}\text { Komponen dan } \\
\text { Ukuran }\end{array}$ & \multicolumn{1}{c}{ Besar } \\
\hline Refrigerator & $1491,4 \mathrm{~W}$ \\
Diameter & $0,4 \mathrm{~m}$ \\
Tinggi & $0,814 \mathrm{~m}$ \\
Tebal & $0.004 \mathrm{~m}$ \\
& $278,15 \mathrm{~K}, 283,15 \mathrm{~K}$, \\
Temperatur & $288,15 \mathrm{~K}, 293,15 \mathrm{~K}$ \\
& (temperatur simulasi) \\
Volume Tangki & 103,7 liter \\
Air Pemanas & \\
\hline
\end{tabular}

Pendinginan air dalam tangki pendingin akan dibantu oleh refrigerator dengan daya 1491,4 W atau setara dengan 2 PK. Tangki pendingin dapat diisi oleh air hingga 103,7 liter. Tangki pemanas memiliki tinggi $0,814 \mathrm{~m}$, tebal $0,004 \mathrm{~m}$ dan diameter $0,4 \mathrm{~m}$. Simulasi dilakukan dengan memvariasikan Temperatur tangki pendingin pada Temperatur 278,15 K, 283,15 K, 288,15 K, 293,15 K.

\subsection{Pengaturan Simulasi}

\subsubsection{Desain}

Simulasi laju aliran pada FASSIP-01 mod.2 menggunakan gambar 2 dimensi yang digambar menggunakan aplikasi Design Modeler yang terdapat dalam aplikasi ANSYS. Ukuran pada gambar menyesuaikan dengan ukuran komponen FASSIP-01 mod.2. Desain 2 dimensi yang digunakan dalam simulasi ditunjukkan pada gambar 5.

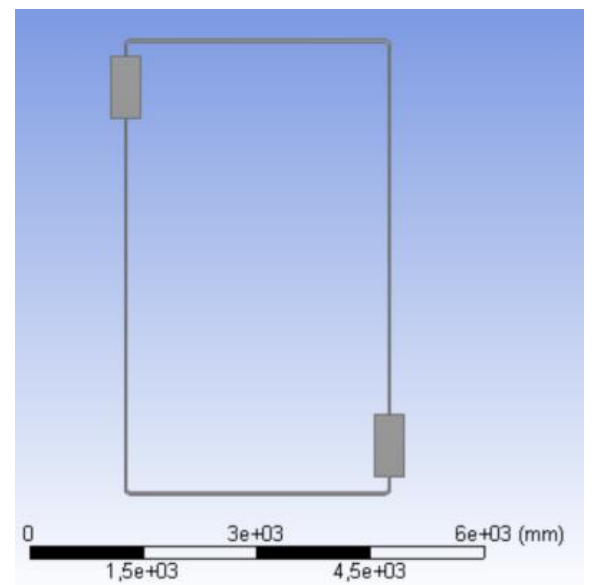

Gambar 5. Desain 2 dimensi FASSIP-01 mod.2.
Desain 2 dimensi FASSIP-01 mod.2 tidak dapat mencakup semua geometri yang ada, maka dari itu beberapa geometri seperti tebal komponen dan flange diabaikan.

\subsubsection{Meshing}

Pengaturan meshing dilakukan dengan mengubah bagian element size menjadi $10 \mathrm{~mm}$ dan element order menjadi linear karena dalam kondisi ini simulasi dianggap lebih teliti dan hemat waktu. Hasil meshing ditunjukkan oleh gambar 6 .

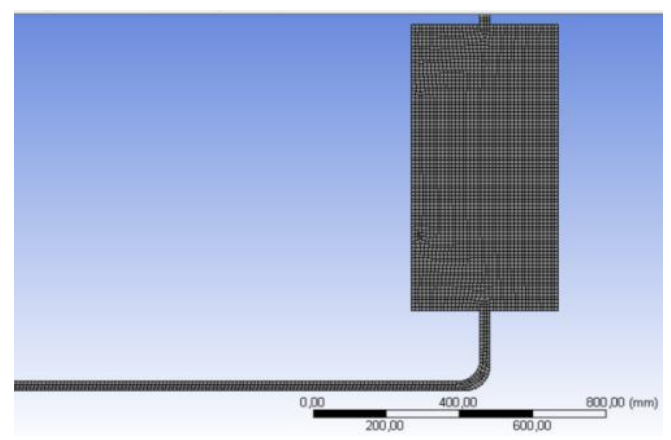

Gambar 6. Hasil meshing desain 2 dimensi FASSIP-01 mod.2.

Tabel 4. Kondisi pengaturan pada simulasi laju aliran FASSIP-01 mod.2.

\begin{tabular}{|c|c|}
\hline Parameter & $\begin{array}{c}\text { Kondisi } \\
\text { Pengaturan }\end{array}$ \\
\hline Double Precision & On \\
\hline \multicolumn{2}{|c|}{ General } \\
\hline Flow type & Density Base \\
\hline Time & Transient \\
\hline Gravity & On \\
\hline Gravitational Acceleration & $Y=-9,81 \mathrm{~m} / \mathrm{s}$ \\
\hline \multicolumn{2}{|c|}{ Models } \\
\hline Energy & On \\
\hline \multicolumn{2}{|c|}{ Materials } \\
\hline Fluid - Water Liquid & $\begin{array}{l}\text { Incompressible } \\
\text { Ideal Gas }\end{array}$ \\
\hline Solid - Steel & Constant \\
\hline \multicolumn{2}{|l|}{ Cell Zone Conditions } \\
\hline Surface_Body & Water Liquid \\
\hline \multicolumn{2}{|l|}{ Boundary Condition } \\
\hline Heater & $\begin{array}{l}278,15 \mathrm{~K}, 283,15 \\
\mathrm{~K}, 288,15 \mathrm{~K} \text { dan } \\
293,15 \mathrm{~K} \\
353,13 \mathrm{~K} \text { dan } \\
363,15 \mathrm{~K}\end{array}$ \\
\hline \multicolumn{2}{|c|}{ Run Calculation } \\
\hline Time Step Size & 1 \\
\hline Number of Time Steps & 700 \\
\hline Max Iterations/Time Step & 10 \\
\hline Reporting Interval & 1 \\
\hline Profile Update Interval & 1 \\
\hline
\end{tabular}


Meshing hanya mengubah bagian kolom defaults dan tetap membiarkan pengaturan lainnya tetap sesuai pada kondisi default (kondisi rekomendasi aplikasi). Setelah selesai proses meshing, maka bagian tangki pemanas dan tangki pendingin diberi nama komponen dengan menggunakan menu named selection untuk langkah setup. Tangki pemanas akan diberi nama heater dan tangki pendingin akan diberi nama cooler.

\subsubsection{Setup (Pengaturan)}

Setup atau pengaturan pada simulasi laju aliran akan disesuaikan dengan kondisi sebenarnya. Pengaturan pada aplikasi simulasi dapat dilihat pada tabel 4. Kondisi double precision diaktifkan pada simulasi karena geometri yang dianggap timpang (memiliki ukuran yang panjang dan tipis). Parameter yang diubah hanya parameter yang ada pada tabel 4 , selain itu parameter tersebut akan diabaikan atau dikondisikan pada kondisi default. Setelah semua parameter telah diatur, maka simulasi dapat dijalankan.

\subsection{Pengolahan Data Simulasi}

Data simulasi yang telah didapatkan diolah menggunakan persamaan-persamaan yang ada untuk mendapatkan variabel lainnya. Variabel yang telah didapatkan dibandingkan satu sama lain agar dapat diketahui karakteristik dari fluida akibat pengaruh variasi. Variabel yang diperoleh dari pengolahan data simulasi adalah sebagai berikut

\section{a. Aliran Massa}

Persamaan untuk mencari besar aliran massa adalah sebagai berikut.

$\dot{m}=\rho u_{m} A_{c}$

Dimana :

$\dot{m}=$ Aliran massa $(\mathrm{kg} / \mathrm{s})$

$\rho=$ Densitas fluida $\left(\mathrm{kg} / \mathrm{m}^{3}\right)$

$u_{m}=$ Cepat laju aliran fluida $(\mathrm{m} / \mathrm{s})$

$A_{c}=$ Luas permukaan pipa $\left(\mathrm{m}^{2}\right)$

Densitas fluida didapatkan berdasarkan tabel 5 .

Tabel 5. Densitas air berdasarkan Temperatur pada tekanan $1 \mathrm{~atm}$ [6].

\begin{tabular}{|c|c|}
\hline Temperatur (K) & Densitas $\left(\mathrm{kg} / \mathrm{m}^{3}\right)$ \\
\hline 353,15 & 971,79 \\
\hline 363,15 & 965,31 \\
\hline
\end{tabular}

Densitas yang diketahui pada tabel 5 dimasukkan kedalam persamaan (1) untuk mengetahui laju aliran massa berdasarkan kecepatan laju aliran.

b. Bilangan Reynold
Persamaan yang digunakan untuk mengetahui Bilangan Reynold dari masing-masing variasi Temperatur adalah sebagai berikut.

$R e_{D}=\frac{4 \dot{m}}{\pi D \mu}$

Dimana :

$R e_{D}=$ Bilangan Reynold

$\dot{m}=$ Aliran massa $(\mathrm{kg} / \mathrm{s})$

$D=$ Diameter pipa bagian dalam $(\mathrm{m})$

$\mu=$ Viskositas dinamis fluida (Pa.s)

Viskositas dinamis fluida berdasarkan tabel 6 .

Tabel 6. Viskositas dinamis air berdasarkan Temperatur [7].

\begin{tabular}{cc}
\hline $\begin{array}{c}\text { Temperatur } \\
\text { (K) }\end{array}$ & $\begin{array}{c}\text { Viskositas Dinamis } \\
\text { (Pa.s) }\end{array}$ \\
\hline 353,15 & 0,000354 \\
363,15 & 0,0003142 \\
\hline
\end{tabular}

Viskositas dinamis fluida yang diketahui pada tabel 6 dimasukkan kedalam persamaan untuk mengetahui besar Bilangan Reynold pada laju aliran berdasarkan variasi Temperatur.

c. Bilangan Nusselt

Bilangan Reynold menentukan jenis aliran yang mengalir pada simulasi laju aliran untai FASSIP-01 mod.2. Laju aliran dengan Bilangan Reynold $\leq 2300$ termasuk kedalam jenis aliran laminar. Menurut R. Shankar Subramanian, untuk mengetahui besar Bilangan Nusselt aliran laminar digunakan persamaan berikut [8].

$N u_{D}=\frac{h D}{k}$

Dimana $k$ berdasarkan tabel 7 .

Tabel 7. Konduktivitas termal air [9].

\begin{tabular}{cc}
\hline $\begin{array}{c}\text { Temperatur } \\
(\mathrm{K})\end{array}$ & $\begin{array}{c}\text { Konduktivitas } \\
\text { Termal Air (W/mK) }\end{array}$ \\
\hline 353,15 & 0,667 \\
363,15 & 0,6729 \\
\hline
\end{tabular}

Sementara itu, menurut penelitian yang dilakukan oleh Dawid Taler dan Jan Taler (2017), untuk mengetahui nilai Bilangan Nusselt pada aliran dengan Bilangan Reynold $3000 \leq \operatorname{Re}_{D} \leq 1000000$ menggunakan persamaan berikut [10].

$N u_{D}=0,01253 \operatorname{Re}_{D}{ }^{0,8413} \operatorname{Pr}^{0,6179}$

Dimana :

$N u_{D}=$ Bilangan Nusselt

$R e_{D}=$ Bilangan Reynold

$\operatorname{Pr}=$ Bilangan Prandtl 
$D=$ Diameter pipa bagian dalam $(\mathrm{m})$

$h=$ Koefisien perpindahan panas $\left(\mathrm{W} / \mathrm{m}^{2} \mathrm{~K}\right)$

$k=$ Konduktivitas termal air $(\mathrm{W} / \mathrm{mK})$

Bilangan Prandtl untuk persamaan (4) berdasarkan tabel 8 .

Tabel 8. Nilai Bilangan Prandtl berdasarkan variasi Temperatur [11].

\begin{tabular}{cc}
\hline Temperatur (K) & Bilangan PrandtI \\
\hline 353,15 & 2,266 \\
363,15 & 2 \\
\hline
\end{tabular}

Berdasarkan tabel 8 nilai Bilangan Prandtl untuk persamaan (4) tidak memiliki syarat nilai untuk Bilangan Prandtl.

\section{Hasil dan Pembahasan}

\subsection{Estimasi Laju Aliran dan Fluks Panas}

Simulasi yang dilakukan menggunakan aplikasi ANSYS (Fluent) dengan memvariasikan Temperatur tangki pemanas pada temperatur $353,15 \mathrm{~K}$ dan $363,15 \mathrm{~K}$, serta memvariasikan temperatur tangki pendingin pada temperatur $278,15 \mathrm{~K}, 283,15 \mathrm{~K}, 288,15 \mathrm{~K}$ dan 293,15 K sebanyak 7000 iterasi. Berdasarkan hasil simulasi, diketahui besar cepat laju aliran dan besar fluks panas pada aliran yang disajikan pada tabel 9 .

Tabel 9. Data hasil simulasi.

\begin{tabular}{ccc}
\hline $\begin{array}{c}\text { Temperatur } \\
\text { Pemanas } \\
(\mathrm{K})\end{array}$ & $\begin{array}{c}\text { Temperatur } \\
\text { Pendingin } \\
(\mathrm{K})\end{array}$ & $\begin{array}{c}\text { Cepat Laju } \\
\text { Aliran (m/s) }\end{array}$ \\
\hline & 278,15 & 0,065 \\
353,15 & 283,15 & 0,058 \\
& 288,15 & 0,051 \\
& 293,15 & 0,043 \\
\hline & 278,15 & 0,0736 \\
363,15 & 283,15 & 0,0739 \\
& 288,15 & 0,067 \\
& 293,15 & 0,059 \\
\hline
\end{tabular}

\footnotetext{
gambar 6 .

Trend data pada tabel 9 bisa dilihat pada
}

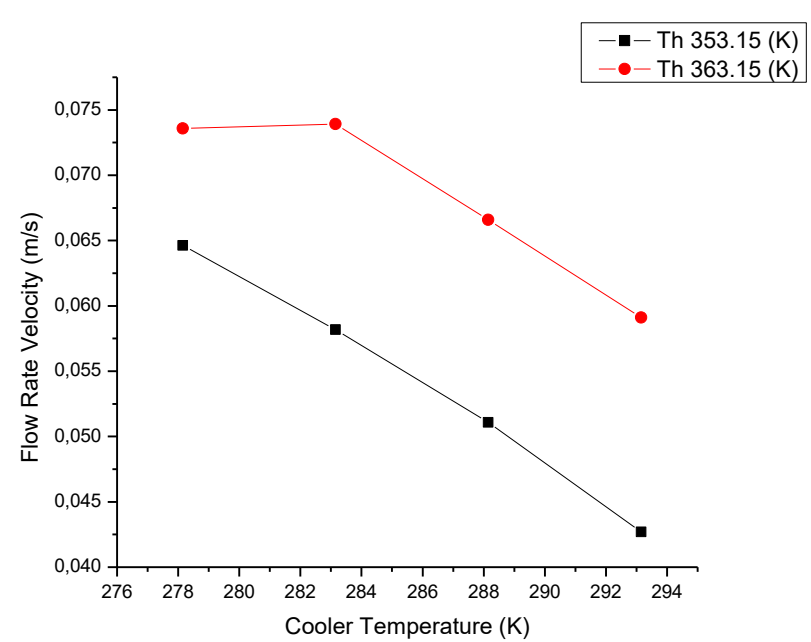

Gambar 7. Pengaruh variasi temperatur terhadap cepat laju aliran.

Pada gambar 7 menunjukkan trend data yang sebagian besar menunjukkan bahwa laju aliran ketika, tetapi pada variasi Temperatur tangki pemanas $363,15 \mathrm{~K}$ cepat laju aliran pada Temperatur pendingin $278,15 \mathrm{~K}$ lebih rendah dibandingkan cepat laju aliran 283,15 K.

\subsection{Estimasi Laju Aliran Massa}

Estimasi laju aliran massa bertujuan untuk memprediksi pengaruhnya terhadap laju perpindahan panas dan karakteristik dari aliran[12]. Estimasi laju aliran massa akan menggunakan persamaan (1) untuk mengetahui laju aliran massa berdasarkan cepat laju aliran. Hasil perhitungan untuk laju aliran massa disajikan dalam tabel 10.

Tabel 10. Hasil perhitungan laju aliran massa.

\begin{tabular}{ccc}
\hline $\begin{array}{c}\text { Temperatur } \\
\text { Pemanas (K) }\end{array}$ & $\begin{array}{c}\text { Temperatur } \\
\text { Pendingin (K) }\end{array}$ & $\begin{array}{c}\text { laju aliran } \\
\text { massa (kg/s) }\end{array}$ \\
\hline & 278,15 & 0,032 \\
353,15 & 283,15 & 0,029 \\
& 288,15 & 0,025 \\
& 293,15 & 0,021 \\
\hline 363,15 & 278,15 & 0,036 \\
& 283,15 & 0,0362 \\
& 288,15 & 0,033 \\
& 293,15 & 0,029 \\
\hline
\end{tabular}

Trend data dari hasil perhitungan pada tabel 10 dapat dilihat pada gambar 8 dan 9 berikut. 


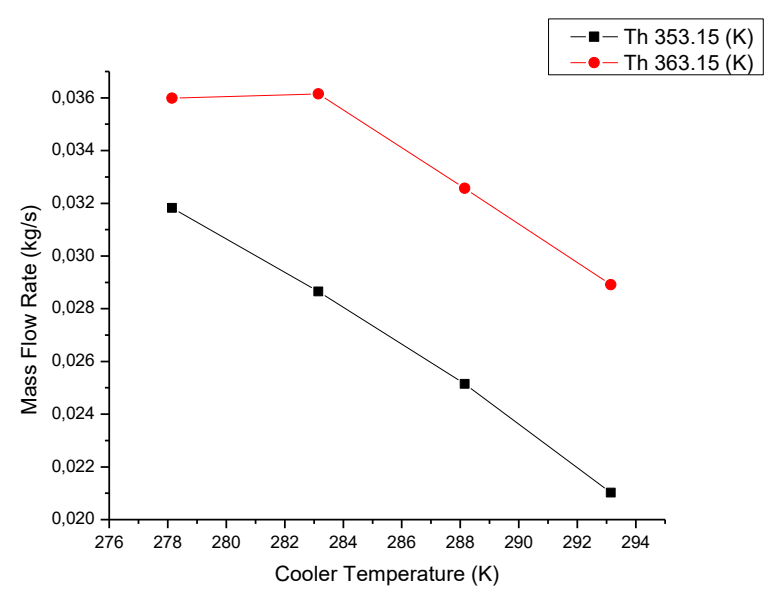

Gambar 8. Laju aliran massa berdasarkan cepat laju aliran.

Gambar 8 menunjukkan trend data menurun yang menunjukkan semakin tinggi temperatur pada tangki pendingin maka laju aliran massa akan semakin berkurang, selain itu, gambar 8 menunjukkan trend data yang sama dengan gambar 6 dimana saat tangki pemanas berada pada Temperatur 363,15 K laju aliran massa pada saat tangki pendingin berada pada Temperatur 283,15 lebih besar dibandingkan pada saat Temperatur 278,15.

\subsection{Karakteristik Aliran}

Karakteristik aliran dapat dilihat dari nilai Bilangan Reynold [13]. Laju aliran massa pada tabel 10 akan dimasukkan kedalam persamaan (2) untuk mengetahui besar dari Bilangan Reynold sehingga didapatkan jenis aliran dari setiap variasi Temperatur. Bilangan Nusselt diketahui jika Bilangan Reynold sudah didapatkan. Nilai Bilangan Reynold yang didapatkan akan dimasukkan kedalam persamaan (4) untuk mengetahui besar Bilangan Nusselt pada aliran. Data hasil perhitungan disajikan pada tabel 11 .

Tabel 11. Nilai Bilangan Reynold dari setiap variasi Temperatur.

\begin{tabular}{cccc}
\hline $\begin{array}{c}\text { Temperatur } \\
\text { Pemanas } \\
(\mathbf{K})\end{array}$ & $\begin{array}{c}\text { Temperatur } \\
\text { Pendingin } \\
(\mathbf{K})\end{array}$ & $\mathbf{R e}_{\mathrm{D}}$ & $\mathbf{N u}_{\mathrm{D}}$ \\
\hline & 278,15 & $4,502,983$ & 24,613 \\
353.15 & 283,15 & $4,064,013$ & 22,578 \\
& 288,15 & $3,568,401$ & 20,238 \\
& 293,15 & $2,973,668$ & 17,36 \\
\hline & 278,15 & $5,743,448$ & 27,961 \\
363.15 & 283,15 & $5,775,356$ & 28,091 \\
& 288,15 & $5,201,012$ & 25,722 \\
& 293,15 & $4,610,713$ & 23,243 \\
\hline
\end{tabular}

Tabel 11 menunjukkan Bilangan Reynold yang diperoleh berdasarkan laju aliran massa. Data pada tabel 11 disajikan dalam grafik perbandingan antara Bilangan Reynold dengan Bilangan Nusselt pada gambar 10 .

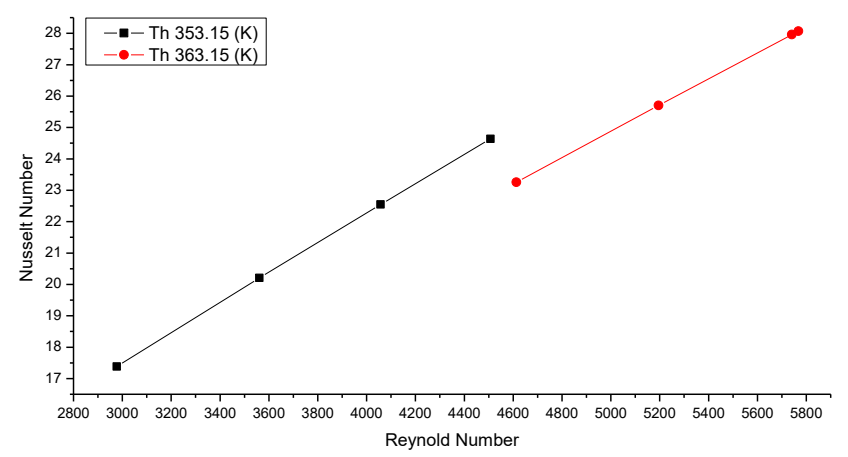

Gambar 9. Hubungan Bilangan Reynold dengan Bilangan Nusselt berdasarkan cepat laju alir fluida.

Pada gambar 9 ditunjukkan Bilangan Reynold berbanding lurus dengan Bilangan Nusselt apabila nilai Bilangan Reynold lebih besar dari.

\section{Simpulan}

Karakteristik aliran pada fenomena sirkulasi alam di untai FASSIP-01 mod.2 dapat diketahui menggunakan variable cepat laju aliran atau heat flux, namun analisa karakteristik aliran dari hasil simulasi ini dilakukan dengan menganalisa cepat laju aliran. Hasil perhitungan menggunakan persamaan-persamaan yang ada menunjukkan bahwa karakteristik berdasarkan cepat laju aliran dan fluks panas memiliki hasil perhitungan yang berbeda. Hasil perhitungan nilai Bilangan Reynold berdasarkan cepat laju aliran adalah 2973,668 paling rendah dan 5775,356 paling tinggi, sedangkan untuk Bilangan Nusselt berdasarkan cepat laju aliran paling rendah didapatkan 17,36 dan paling tinggi 28,091. Hasil perhitungan menunjukkan bahwa jenis aliran sebagian besar berjenis turbulent karena memiliki nilai Bilangan Reynold $\mathrm{Re}_{\mathrm{D}} \geq 4000$ dan ada beberapa kemungkinan aliran berjenis aliran transisi karena memiliki nilai Bilangan Reynold $2300 \leq \mathrm{Re}_{\mathrm{D}} \leq 4000$.

\section{Ucapan Terima Kasih}

Ucapan terima kasih penulis sampaikan kepada anggaran riset dari CRP-IAEA dengan nomor kontrak 20948 tahun 2017-2021, serta kepala PTKRN - BATAN beserta anggota laboratorium termohidrolika yang telah mengizinkan dan memberikan fasilitas kepada penulis untuk melakukan penelitian pada untai FASSIP-01 mod.2. Penulis juga menyampaikan ucapan terima kasih kepada Program Studi Teknik Mesin Universitas Udayana yang telah mengadakan kegiatan Program Magang Industri 
sehingga penulis mendapat izin untuk melakukan penelitian di PTKRN-BATAN.

\section{Daftar Pustaka}

[1] R. Rachmawati, Indonesia Akan Miliki Pembangkit Listrik Tenaga Nuklir Pertama, $2020 . \quad$ [https://www.pikiranrakyat.com/nasional/pr-01335010/indonesiaakan-miliki-pembangkit-listrik-tenaga-nuklirpertama] (diakses 7 Mei 2021).

[2] BAPETEN, Kecelakaan Reaktor Nuklir Fukushima Dai'ichi di Jepang, Radiasinya tidak Sampai ke Indonesia, 2011. [https://bapeten.go.id/berita/kecelakaanreaktor-nuklir-fukushima-daiichi-di-jepangradiasinya-tidak-sampai-ke-indonesia-134718] (diakses 7 Mei 2021).

[3] M. Juarsa, Giarno, A. N. Rohman, G.B. Heru K., J.P. Witoko, D.T. Sony Tjahyani, Flow rate and temperature characteristics in steady state condition on FASSIP-01 loop during commissioning, Proceeding ICoNETS 2017, 962, 2018.

[4] A. Rinaldi, L. Gabriella N, Giarno, J. Prasetio, M Juarsa, Estimasi Laju Aliran Sirkulasi Alam Berdasarkan Beda Temperatur Pada Untai Fassip-01, Buletin IImiah Sigma Epsilon, Vol.23 No.2, 2019.

[5] M. Noufal, I.G.B Wijaya Kusuma, I N. Suarnadwipa, Analisa Perpindahan Panas Pada Heater Tank FASSIP - 01, Jurnal METTEK Volume 3 No.1, 1-10, 2017

[6] Engineering ToolBox, Water - Density, Specific Weight and Thermal Expansion Coefficient, 2003.

[https://www.engineeringtoolbox.com/waterdensity-specific-weight-d_595.html] (diakses 8 Mei 2021).

[7] Engineering ToolBox, Water - Dynamic and Kinematic Viscosity, 2004. [https://www.engineeringtoolbox.com/waterdynamic-kinematic-viscosity-d_596.html] (diakses 8 Mei 2021).

[8] R. Shankar Subramanian, Heat Transfer in Flow Through Conduits, Unknown. [https://linweb.clarkson.edu/projects/subramanian/ch330 /notes/Heat\%20Transfer\%20in\%20Flow\%20T hrough\%20Conduits.pdf] (diakses 8 Mei 2021).

[9] Engineering ToolBox, Water - Thermal Conductivity, 2018. [https://www.engineeringtoolbox.com/waterliquid-gas-thermal-conductivity-temperaturepressure-d_2012.html] (diakses 19 Mei 2021).

[10] D. Taler and J. Taler, Simple Heat Transfer Correlations For Turbulent Tube Flow, WTiUE 2016, E3S web of conferences 13 (2017).

[11] Online Library, APPENDIX B: Thermophysical Properties of Water, Unknown. [https://onlinelibrary.wiley.com/doi/pdf/10.1002 /9781118534892.app2] (diakses 8 Mei 2021).

[12] A.R.P Adi dan I M. Arsana, Analisa Pengaruh Laju Aliran Massa Fluida Dan Temperatur
Fluida Masuk Terhadap Kapasitas Radiator Pada Sistem Pendingin Daihatsu Xenia 1300 Cc, Jurnal Pendidikan Teknik Mesin Volume 6 Nomor 3, 1-9, 2018.

[13] P. Nugroho, Bilangan Reynolds Untuk Aliran Evaporasi Dua Fasa Pada Kanal Mini Horizontal Dengan Refrigeran R-290 Dan R600A, Skripsi, Program Studi Teknik Mesin, Fakultas Teknik, Universitas Indonesia, 2012.

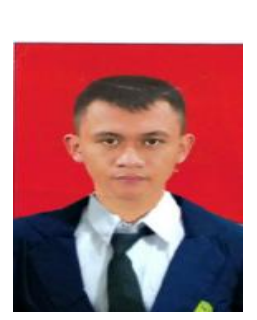

Nathaniel Ezer Putra Darmawan mahasiswa Program Studi Teknik Mesin Fakultas Teknik Universitas Udayana. Pada bulan September 2020 memiliki kesempatan melakukan magang di PTKRN-BATAN selama 8 bulan. Selama magang menjadi salah satu yang mendapat proyek untuk memodifikasi untai FASSIP-01. Fokus penelitian yang sedang dijalankan adalah mengenai laju aliran pada untai FASSIP-01 mod.2. 